\title{
DE GREGÓRIO DE MATOS A CAETANO VELOSO E «OUTRAS PALAVRAS»: BARROQUISMO NA MÚSICA POPULAR BRASILEIRA CONTEMPORÂNEA
}

POR

CHARLES A. PERRONE

University of Texas

Durante um seminário de cultura e literatura brasileira promovido por uma editora do Rio de Janeiro há já tres anos, um crítico e professor conhecido, coordenador das atividades intelectuais naquela ocasião, opinou que aplicar conceitos de poética à música popular era «forçar a barra». O que o distinguido estudioso queria dizer, valendo-se de uma linguagem atual para dirigir-se a um auditório composto na sua maioria de jovens principiantes no estudo cultural, era que as canções compostas por artistas do dia não constituiam um objeto estético digno de considerações por parte dos analistas sérios dos fenômenos literários. Replicandolhe em termos igualmente atuais, se poderia tachar o sujeito em questão de «careta» ou de «não sacar nada». Considerando o tema desde um ângulo mais "sério», poderia dizer-se que tal asseveração mostra uma atitude antiquada e pouca aberta às realidades estéticas do Brasil de hoje em dia. Enquanto este e inumeráveis outros mantêm uma linha conservadora, fechada face às inovações do fazer artístico brasileiro e às digressões do caminho convencional, outras mentes, algumas há já quinze anos, reconhecem o valor estético dos setores mais criativos da música popular e trabalham sobre seu corpus lírico. O poeta-crítico Augusto de Campos, cuja atualidade e criatividade já mostram sua solidez na prática e polêmica da poesia concreta dos anos cinquienta, foi o primeiro a chamar a atenção para os fenômenos poéticos inusitados do grupo baiano na década dos sessenta. Em artigos que logo mais seriam colecionados no volume Balanço da bossa ${ }^{1}$, o perspicaz comentador da música popular dava a en-

\footnotetext{
1 Augusto de Campos, Balanço da bossa (São Paulo: Perspectiva, 1968. Segunda
} edição aumentada, Balanço da bossa e outras bossas, 1974). 
tender que o que estava havendo naqueles primeiros dias tropicalistas não representava uma simples importação de formas musicais nem tão só uma revolução no som; tratava-se de formulações artísticas que envolviam uma abordagem sofisticada à linguagem lírica, as quais se ligavam intimamente à história dos momentos inovativos da poesia brasileira. Por sua conta, Haroldo de Campos registra a importância da explosão líricomusical do grupo baiano em um estudo global e atualizado dedicado às literaturas da América Latina (1972) ${ }^{2}$. Um ano depois o professor-poeta Affonso Romano de Sant'Anna, em artigos jornalísticos, assinalava os procedimentos de linguagem significativos nos textos de Caetano Veloso e começava a vincular os de Chico Buarque com a série literária também. Os estudos do criador-pesquisador mineiro culminaram na coletânea $M u ́$ sica popular e moderna poesia brasileia (Petrópolis: Vozes, 1978), onde afirma a necessidade de estabelecer um «Interregno da música popular» na história da poesia contemporânea à vista de tamanha produção poética associada ao campo musical até 1973. Augusto de Campos coloca a situação de forma mais enfática:

Se quiserem compreender esse período extremamente criativo de nossa vida artística, os compêndios literários terão que se entender com o mundo discográfico. No novo capítulo da poesia brasileira que se abriu apartir de 1967, tudo ou quase tudo existe para acabar em disco.

(Pórtico do exemplar «Caetano Veloso» da Nova História da Música Popular Brasileira, São Paulo: Abril Cultural, segunda edição, 1977.)

Esta idéia foi independente e teoricamente trabalhada por Anazildo Vasconcelos da Silva, um jovem professor da Faculdade de Letras da UFRJ, que publicou A poética do Chico Buarque (Rio: Sophos, 1974). O pórtico deste livro, podendo aportar certo elemento de surpresa para algum leitor eventual, mostra até onde a admiração pelos poetas-compositores chegara em princípios da década passada:

A meu ver, o maior poeta da geração nova é Chico Buarque de Hollanda. É preciso não esquecer que a sua música veicula ou se associa a uma das mais altas e requintadas formas da poesia lírica.

(Correio da Manhã: Anexo. 5-01-72. Afrânio Coutinho.)

\footnotetext{
${ }^{2}$ América latina en su literatura (México: XXI-Unesco, 1972). Para uma versão maior do artigo «Superación de los lenguajes exclusivos»: Ruptura dos gêneros na literatura latinoamericana (São Paulo: Elos-Perspectiva, 1977).
} 
Continuar a documentar a aceptação de determinados representantes da música popular por críticos da área literária seria alongar demasiadamente esta introdução, pois desde aqueles anos muitos têm-se ocupado de considerar as aportações líricas de certos compositores ou parceirospoetas ao acervo poético brasileiro. É proveitoso considerar, contudo, uma declaração crítica conclusiva feita pelo Professor Vasconcelos da Silva após uma avaliação estética da produção lírico-musical de sua geração:

E o saldo de tudo isso é, no presente momento, a significativa obra poética de alguns compositores que terão de figurar ao lado de nossos melhores poetas, sem nenhum favor ${ }^{3}$ (grifo nosso).

Uma vez colocada a validez de quebrar a fronteira artificial entre o campo poético e o campo da canção - divisão inexistente nas origens trovadorescas da lírica - resulta ainda atrevido, em termos de história literária tradicional, afirmar uma conexão entre o remoto passado das letras luso-brasileiras e a época contemporânea da canção. É exatamente isso, não obstante, o que se vem a propôr neste ensaio, como o mesmo título o indica. Determinados momentos do lirismo da música popular dos últimos quinze anos representam uma modalidade barroca, ou neobarroquista, associável à sensibilidade poética da época de Gregório de Matos. Este barroquismo lírico-musical —por não falar em um ressurgimento do Barroco enquanto estilo epocal ou movimento- presencia-se seletivamente na série da canção brasileira enquanto atitude artística estruturadora de textos e enquanto atualização de certos estilemas historicamente fixados no Seiscentos. Esta noção de barroquismo deverá ficar mais esclarecida a medida que se for examinando alguns textos exemplares do periodo cronológico estabelecido para fins deste ensaio.

Pois bem, do mesmo modo que é necessário ampliar os conceitos de literatura ${ }^{4}$ para incluir textos da música popular na constatação e análise dos fenómenos literários, é preciso manejar uma concepção flexível da história literária, ou adotar uma ótica de novas sensibilidades, para falar em aspectos estilisticos irmãos em épocas distantes no tempo, épocas que a historiografia literária mais tradicional ou rígida manteria separadas por

\footnotetext{
${ }^{3}$ Anazildo Vasconcelos da Silva, «A Paraliteratura», em Teoria Literária (Rio de Janeiro: Tempo Brasileiro, 1976), p. 184.

${ }^{4}$ Além dos estudos citados, ver Affonso Romano de Sant'Anna, Por um novo conceito da literatura (brasileira) (Rio de Janeiro: El Dorado, 1977), e Anazildo Vasconcelos da Silva, Lírica modernista e percurso literário brasileiro (Rio de Janeiro: Rio, 1978).
} 
completo. E se vai falar-se em barroquismo na música popular brasileira contemporânea, convêm assinalar a atualidade e vigência de abordagens históricas que poderiam orientar tal tipo de aproximação aos textos.

No âmbito brasileiro, coube a uma mentalidade moderníssima e sensível às veleidades da musa lírica ao longo dos séculos chamar a atenção crítica para novas possibilidades de pensamento histórico no que se refere específicamente às áreas literárias. Haroldo de Campos, pensador sintético mais ligado à própria criatividade do que à oficialidade acadêmica, tratou polemicamente o assunto da leitura estético-histórica no Brasil em um artigo ideado apartir das formulações linguiísticas de Ramon Jakobson: «Por uma poética sincrônica» (in A Arte no horizonte do provável, São Paulo: Perspectiva, 1969). A idéia regedora desta contribuição é que uma abordagem estilística de corte sincrônico — vs. diacrônico linear- permite enfocar paradigmaticamente diferentes vozes poéticas em épocas distintas como integrantes de um diálogo textual. Esta espécie de ótica histórica, associável à abertura estética forjada pelo ensaista italiano Umberto Eco com sua obra Obra aberta (1962) ${ }^{5}$, é que dá lugar a consideracões transtemporais no campo artístico que muito poderão ter a dizer sobre as formas em que o homem universal se exprime através da palavra (escrita ou cantada).

No espaço literário latinoamericano, o trabalho do cubano Severo Sarduy se destaca como orientação fundamental e indispensável para quem se aproxima dos fenômenos linguísticos barrocos em nossos dias. Seu livro Barroco (Buenos Aires: Sudamericana, 1974) trata, acima de tudo, a cosmologia européia nos séculos que comumente se associam com a produção artística barroca generalizada, mas em um suplemento ao texto maior reflete sobre o significado da prática do barroco atual. Estas reflexões são longamente desenvolvidas em um trabalho, que acompanha o de Haroldo de Campos primeiramente referido acima, em América Latina en su literałura: «El Barroco y el Neo Barroco». Os parâmetros invocados na visão abrangente e reveladora do prosista cubano -artifício, substituição, proliferação, condensação; paródia, inter e intratextualidade; erotismo e espelho- oferecem possibilidades analíticas que muito terão a dizer sobre o texto latinoamericano atual, inclusive determinados casos da música popular do Brasil. O importante no enfoque de

${ }^{5}$ Para indicar desde quando datam as intenções inovadoras no Brasil, no que diz respeito à avaliação histórico-estética da literatura nacional, ver «A obra de arte aberta» de Haroldo de Campos, em Teoria da poesia concreta (São Paulo: Duas cidades, 1975), e "Da razão antropofágica», do mesmo autor (Colóquio de Letras, no. 62, julho 1981); Ainda, "Texto e história», em Operação do texto (São Paulo: Perspectiva, 1977). 
Sarduy é a ênfase nos procedimentos lingüísticos e na concepção implícita da criação, e no próprio texto verbal, independentemente de sua época. Reduzir o conceito do barroco (ou de qualquer estilo) a uma visão artística e eventualmente filosófica restringida a um certo periodo diacrônico, é claro, elimina a possibilidade de co-relacionar sensibilidades poéticas através dos séculos ${ }^{6}$. É precisamente por meio de um enfoque das funções da linguagem (à la Jakobson) e por meio da detectação de uma sensibilidade de estruturação atrás do texto (atitude lírica, noção criativa, «approach» poético) que se pode falar em elementos barroquistas em textos fora do mesmo eixo diacrônico, mas atingidos por um eixo de corte sincrônico.

O conceito de sincronia verbal não pretende nem deve implicar paralelos ou identificações a níveis extra-linguiísticos ou artísticos. Seria até absurdo propôr, na época de viagens espaciais e de computadoras que manejam em micro-segundos bilhões de itens de informação, que haja condições sócio-econômicas ou correntes de pensamento religioso ou científico equiparáveis, realmente comparáveis, com aquelas que formavam parte do mundo que se sacudia com o descentramento cosmológico referido por Sarduy. Contudo, é proveitoso observar como certas generalidades podem refletir alguma luz sobre a produção artística de generações posteriores:

No barroco, criador da ópera e da polifonia, a cultura inteira se musicaliza segundo a penetrante intuição de Spengler: a alma fáustica se abandona por completo à embriagtuez do infinito?

Estas palavras de José Guilherme Merquior vêm sugerir no contexto duas características do produtor artístico do Seiscentos significativas para seus herdeiros: a exuberância e o sensualismo, o qual se funde com o voluntarismo «na volúpia da metamorfose e da ostentação». Esta última se traduz na literatura, conforme a interpretação de Merquior, no cultismo e no conceitismo, «duas faces dessa mesma tendência lúdica, ornamental e efeitista».

Sem querer restar o que têm de importantes os dois últimos elementos para a poética dos tempos de Góngora e Quevedo (e eventualmente para

${ }^{6}$ Para apenas dois exemplos desta posição mais tradicional, ver Rene Wellek, "The Concept of Baroque in Literary Scholarship», em Concepts of Criticism (New Haven: Yale Press, 1963), e no Brasil, Afrânio Coutinho, Introdução à literatura no Brasil (Rio de Janeiro: Sul Americana, 1970, cap. sobre o barroco).

${ }^{7}$ José Guilherme Merquior, «Os estilos históricos na literatura ocidental», em Teoria literária, cit., p. 49. 
letras musicais atuais) convém sublinhar o primeiro dos elementos -o lúdico - porquanto representa um aspecto fundamental da concepção artística da explosão barroca de há séculos, e porquanto facilita uma aproximação transtemporal aos textos baseada nas funções da linguagem, especialmente a «poética» e a «metalingüística». Em um estudo singular ao respeito, $O$ Lúdico e as projeções no mundo barroco (São Paulo: Perspectiva, 1971), o escritor brasileiro Affonso Ávila vincula o fazer poético da época de Gregório de Matos e o moderno, avaliando a proposição de Schiller de que o jogo é fator básico da arte, ao dizer que ela «vem em abono da arte desse exímio jogador que foi o homem barroco e ao mesmo tempo nos encaminha para a assimilação mais franca da constante formulação lúdica que permeia a linguagem de nossos dias» (p. 22).

O mero fator de portar características lúdicas não daria uma etiqueta barroca a um texto contemporâneo, mas apontaria para a região construtora da consciência artística onde poderiam detectar-se outras comunicações extra-temporais entre contemporâneos e antepassados líricos longínquos.

Para James Amado, o escritor baiano que corajosamente levou a cabo a tarefa de editar as obras completas da maior figura do barroco brasileiro, o «Boca do Inferno», é lícito aproximar ao objeto de seu trabalho outra voz arquiconhecida de sua terra natal através dos seguintes pontos de contato:

Desempenhando na sociedade de consumo papel contestador e jogralesco semelhante ao do seu antepassado seiscentista no "gran teatro del mundo» close quate barroco, o artista jogador, o artista síntese de nossos dias também sobe ao palco dos modernos auditórios da massa, exibindo sua arte ou exibindo-se a si mesmo, sob a roupagem de poeta, cantor e clown no grande happening de um mundo de angústias e desajustes. $\mathrm{E}$ razão não faltou ao editor mais recente de Gregório de Matos, quando pareceu ver na música jovem e inconformada de Caetano Veloso a ascendência remota mas vivificada do Boca do Inferno, ambos falando a mesma linguagem tropical e desmistificadora, poetas e baianos, jograis de viola ou guitarra, jogadores ambos, retomando o de hoje o mesmo dado com que o outro, há 300 anos, apostou e aparentemente perdeu -mas só aparentemente- no mesmo jogo de revés que é o jogo de toda arte.

$$
\text { (Affonso Ávila, p. 100) }{ }^{8} \text {. }
$$

${ }^{8}$ Affonso Ávila refere-se ao artigo introdutório de James Amado, «A foto proibida há 300 anos», em Gregório de Matos. Obras completas (Salvador: Januária, 1968), vol. I, pp. xxvi-xxvii. A recriação significativa de Caetano Veloso é salientada ainda por José Miguel Wisnik, introdução a Gregório de Matos. Poemas Escolhidos 
Os analistas e comentaristas da obra de Caetano Veloso, o mais destacado dos novos baianos, não focalizaram per se elementos barroquistas em seu trabalho textual, mas o que a obra dele oferece de fecundo no que diz respeito à consciência e prática linguiística eventualmente associáveis a um diálogo com o barroco, está sucintamente exposto nos artigos acima referidos de Augusto de Campos e de Affonso Romano de Sant'Anna (especialmente «O Múltiplo Caetano»). Além das observações destes poetas - cujo engajamento nas lidas atuais da palavra poética deve permitir-lhes acesso mais rápido aos caminhos criativo-analíticos que desviam da estrada reta da oficialidade- existem vários outros estudos que vinculam Caetano e a herança literária que recebeu. Entre estes o tratamento dado ao aspecto da paródia, lembrando os parâmetros de Sarduy, mereceria consideração séria na avaliação da contribuição de Caetano ${ }^{9}$. Ademais, como participante destacado do movimento tropicalista, Veloso formava parte de um grupo artístico cuja ampla consciência histórica indica-se num verso de Torquato Neto na canção «Geléia Geral»: «... santo barroco baiano...» O sincretismo e a revisão estética essenciais ao projeto tropicalista incluem uma (re)apreciação dos fenômenos barrocos, e a nova roupagem velosense para (parte de) o soneto «Triste Bahia» de Gregório de Matos -embora fruto do primeiro momento pós-tropicalista- evidencia este fato.

Compositor da música de «Geléia Geral» (expressão cunhada por Décio Pignatari no editorial de apresentação do número 5 da Revista Invenção, 1966) e constante companheiro do compositor de "Tropicália» até a volta dos dois do exílio em Londres, Gilberto Gil também assinou canções na década de sessenta que mostram um carater lúdico, eminentemente metalingüístico, se bem que suas parcerias com poetas como

(São Paulo: Cultrix, 1976), p. 19; Haroldo de Campos, «Da razão antropofágica», op. cit., e Antônio Risério Filho, "O nome mais belo do medo», em Minas Gerais Suplemento Literário (21 julho 1973), onde discute o ludismo moderno de Caetano. Sobre o comportamento e o discurso do artista, ver: Silviano Santiago, «Caetano Veloso enquanto superastro» e "Bom conselho», em Uma literatura nos trópicos (São Paulo: Perspectiva, 1978).

9 Ver Celso Favaretto, Tropicália: Alegoria Alegria (São Paulo: Kairós, 1979), e Nadiá Paulo Ferreira, "Tropicalismo: Retomada oswaldiana», em Vozes, LXVI, no. 10 (1972). Há ainda a considerar a dissertação de mestrado, inédita em livro, de Marilena de Lauro Montanari, «O Poema-Canto, Gerado na dialética: música popular, texto literário» (PUCSP, 1980), onde é estudado em retrospecto síncronodiacrônico o passado da poesia/música desde os trovadores como pano de fundo para o estudo da linha de invenção na música popular brasileira, especialmente a Tropicália. Nesta dissertação, desenvolvida sob a orientação de Haroldo de Campos, o barroco é uma das fases significativas analisadas pela autora. 
Campinan e Torquato Neto sejam as canções que mais chamam a atenção para 0 aspecto lírico. Gil afirma o papel da brincadeira na poética tropicalista em que participou em um depoimento prestado numa sessão da Expoesia (PUC, Rio, 1973). Na década de setenta, porém, Gil adota um «pose» que entra no limiar do catequético. Estas tendências percebem-se em uma canção de fé mística e título irônico, «Se oriente rapaz», conforme observa Affonso Romano de Sant'Anna ${ }^{10}$.

Esta nova orientação produz curiosos resultados nas letras do «guruastro» que parecem ter bebido na fonte do catequismo jesuita barroco para buscar efeitos persuasórios, apontados por Ávila como um dos tres elementos básicos do barroco ao lado do lúdico e da visualidade. Desta maneira, «Copo vazio» (título previamente usado por Aldary de Almeida Ayrão e Linda Lemos de Araujo) começa com uma exhortação filha dos sofisticados conceitos antitéticos barrocos:

$$
\begin{aligned}
& \text { É sempre bom lembrar } \\
& \text { Que um copo vazio } \\
& \text { Está cheio de ar... }
\end{aligned}
$$

Se estes versos parecerem até se aproveitar de um cliché paradoxal da filosofia amadora, o desenvolvimento do texto lírico supera esse nível porquanto troca engenhosamente os conteúdos da juxtaposição para chegar a sua conclusão:

Uma metade cheia uma metade vazia Uma metade tristeza uma metade alegria A magia da verdade inteira Todo o poderoso amor.

(Gravação de Chico Buarque, Sinal fechado, Phillips 6439-122, 1974.)

O espiritualismo dos contra-equilíbrios e do amor universal que Gil lança aqui, e em outras enunciações, não enquadra certamente com o do Deus católico ou do amor idílico que poderiam ter cantado os bardos do Seiscentos, mas os seus métodos retóricos, se se quiser, exibem correspondências inegáveis. Se o compositor talvez evite um nível demasiadamente sofisticado por questôes de receptividade —isto é adequar o texto a um público não necessariamente muito «culto»- a forma retórica fundamental não deixa de refletir certa afinidade com a dos tempos do Padre Vieira.

${ }^{10}$ Ver pp. 238-244 de Romano de Sant'Anna, Música popular. O título verdadeiro é «Oriente»; o que ele cita é o primerio verso. 
O raciocínio vital de ressonância conceitista aparece da mesma sorte na música conclusiva «Então vale a pena»:

Se a morte faz parte da vida

E se vale a pena viver

Então vale a pena morrer...

(Gravação de Simone, EMI Odeon 064421089D.)

Outra vez os termos do silogismo - ou paródia dele- parecem ser tirados do repertório do lugar comum ou cliché filosófico, mas será exatamente essa familiaridade que presta eficácia ao enunciado.

Se estas citações de Gil parecerem algo isoladas, a letra da música «Aqui e agora» ${ }^{11}$ é uma verdadeira festa de sensibilidade poética barroca transferida para o espiritualismo moderno de um jogral iluminado. É uma sucessão de quadras regidas pelo refrão do título que se estrutura sobre noções enigmáticas do complexo tempo-espaço. $O$ texto se auto-caracteriza no primeiro verso: «Aqui onde o indefinido...» e propõe uma ente extra-sensorial de corte algo emotivo e meio misterioso: "Aqui onde o olho mira / Agora que o ouvido escuta / O tempo que a voz não fala / Mas que o coração tributa...» Logo mais o relacionamento tempoespaço se confunde em uma justaposição antitética que contribui ao aparente paradoxo em vias de desenvolvimento: "Aqui onde a cor é clara / Agora que é tudo escuro...» Este jogo entre claro e escuro na figura do oxímoron corresponde a figuras clássicas da poesia barroca, conforme elucidam numerosos estudiosos do estilo epocal, entre eles o lusitano Saraiva ${ }^{12}$.

Em conjunto, os versos da música não configuram nada concreto nem identificável; o tempo da vida ou da morte, do antes e do depois, o lugar do dentro ou do fora, do perto ou do longe, é tudo relativizado numa ambiguiidade polissêmica que conduz tão só ao questionamento ou à maravilha perante o texto. E esta elaboração efêmera lembra a comparação de Umberto Eco entre a arte anterior e a arte de contribuição renovadora do criador barroco, tendendo este a

${ }^{11}$ Do disco Refavela (Phonogram 6349-329). Retomando a linha dos paralelos entre Gil e o mundo anglo-americano, merece comparação aqui a canção «Here There and Everywhere» de The Beatles, música que sugere a ubiqüidade de um espírito vital no estilo desta música de Gil.

${ }_{12}$ António José Saraiva e Oscar Lopes, História da literatura portuguesa (Oporto: Porto Editora, s/data, 5. edição, 1967?). 
establecer esta tarea inventora del hombre nuevo que ve en la obra de arte no un objeto fundado en relaciones evidentes para gozarlo como hermoso, sino un misterio a investigar, una tarea a perseguir, un estímulo a la vivacidad de la imaginación ${ }^{13}$.

Havendo a possibilidade de uma resposta espiritualista ao enigma metaforizado de «Aqui e agora», Gilberto Gil se debruça metalingüísticamente sobre a própria criação em uma composição de seu penúltimo LP Realce (cujo título vem participando de um jogo renovador auto-referente: Refavela, Refazenda, «Retiros espirituais», Refestança...). «Rebento» descreve uma série de ocasióes ou momentos afetivos ligados por esse denominador comum, mas sem esclarecimento:
Rebento, substantivo abstrato
$\mathrm{O}$ ato, a criação, o seu momento
Como uma estrela nova
Que só Deus sabe lá no firmamento
Rebento, tudo que nasce é rebento...
Rebento, este trovão dentro da mata
E a imensidão do som desse momento.

(Gravação do compositor, WEA BR 32038,1978 .)

A canção é um exercício de substituição, metaforização e metonimização, cujo deslinde do enigma ou do efêmero depende da auto-referência, da função auto-consciente e metalinguíística da linguagem com que se constrói o texto. E é assim, em espírito, atualização do barroco.

Gil e Caetano, como integrantes originários do projeto tropicalista, consideraram propositadamente a herança lírico-musical brasileira que remonta até o Barroco. A obra de outros compositores de formação distinta mostra um carater não menos barroquista em certos casos, se bem que isto se dê frequientemente por outros caminhos.

$\mathrm{Na}$ obra de um autor da estatura de Chico Buarque de Hollanda, homem de uma consciência histórico-artística muito ampla, que tem produzido tantas criações maravilhosas e sutis, não surpreende encontrar resíduos da poética barroca do engenho e/ou traços do neo-barroco latinoamericano. Sem querer implicar uma relação de causa e efeito, é também interessante o fato de Sérgio Buarque de Hollanda — pai do músicoter-se ocupado extensamente da história da colônia brasileira e de ter

${ }^{13}$ Umberto Eco, Obra abierta, tradução espanhola (Barcelona: Arie1, 1979), p. 7. 
sido organizador da Antologia dos poetas brasileiros da fase colonial (reedição, São Paulo: Perspectiva, 1979). A eficácia estética de suas composições musicais dos últimos quinze anos não poucas vezes deve-se à sua capacidade para transmitir mensagens eróticas ou sociais através de um processo singular de justaposição, metaforização e elaboração estrutural, processo permeado por aspectos verbal e ideologicamente lúdicos. Já no primeiro trabalho editado pelo jovem poeta-cantor revela se uma poética em uma série metafórica comparativa:

Tem mais samba no encontro que na espera

Tem mais samba a maldade que a ferida

Tem mais samba no porto que na vela

Tem mais samba o perdão que a despedida

Tem mais samba no chão do que na lua...

(Gravação RGE Fermata 303.0003, vol. I, 1966) ${ }^{14}$.

A fusão do jogo fonético e do sentido socialmente engajado é outro momento liricamente destacado do primeiro LP de Chico Buarque:

Pedro Pedreiro penseiro esperando o trem

Manhã parece carece de esperar também

Para o bem de quem tem bem

De quem não tem vintém...

Esperando o dia de esperar ninguém

Esperando nada mais além

Do apito do trem...

Que já vem que já vem que já vem.

No primeiro nível, «Pedro Pedreiro» é um retrato de um operário de subúrbio desesperançado, mas conforme a análise de Anazildo Vasconcelos da Silva ${ }^{15}$, a linha convergente dos significados enunciados resulta em um englobamento pelo sujeito lírico, que pode ser definido pelo parâmetro da condensação, proposto pelo modelo neo-barroco de Sarduy.

Em «Agora falando sério» a reflexão estética informa um texto construído a partir de uma intertextualidade e de uma metáfora paradoxal, até oximoronal.

${ }^{14}$ Ver o estudo semiológico de Anazildo Vasconcelos da Silva, em Desconstrução e construção no texto lírico (Río de Janeiro: Fco. Alves, 1975).

${ }^{15}$ Vasconcelos da Silva, A Poética, p. 25. 


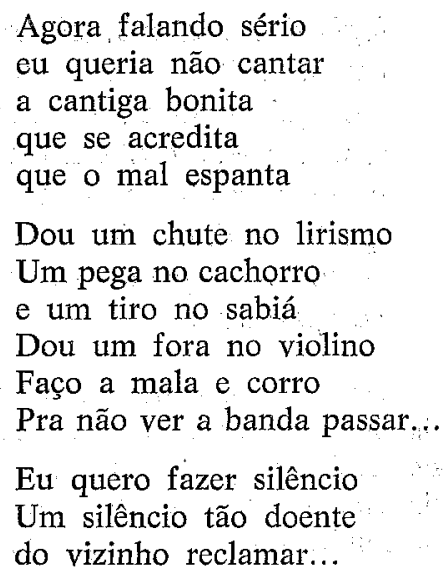

(Gravação CBD R 76.106, vol. 4, 1969.)

Como canção o texto expõe o desejo de falar e de não cantar enquanto canta, sendo o silêncio barulhento o objetivo; para tal o cantante/falante lírico rejeita o canto proverbial, o lirismo em geral, e seus próprios antecedentes ( Sabiá» com Jobim, a famosa «A Banda» do $1 .^{\circ} \mathrm{LP}$ ). No fim das contas este exemplo da expressão buarquiana projeta um halo satíricomisterioso sobre a palavra cantada do seu tempo, procurando quiçá a recuperação de um espaço comunicativo integrado.

É no par «Construção-Deus the pague» onde mais nitidamente percebem-se elementos de barroquismo nas músicas de Chico Buarque. O título da primeira, além de assinalar o setor específico da sociedade ao redor da qual o texto gira tematicamente, anuncia a própria textura da canção, pois mais do que qualquer texto que conhecemos no âmbito da música popular os versos da música constroem uma fábrica lingüística e ideológica que parece arquitectônica. Assim, o signo que indica o referente concreto (a atividade construtora, o prédio que se faz) é simultâneamente auto-identificação do texto a que pertenece, que por seu turno comenta aquele referente concreto: «Ergueu no patamar quatro paredes sólidas... mágicas... flácidas... Tijolo com tijolo num desenho mágico... lógico...» (gravação CBD Phonogram 6349017, 1970).

As quatro paredes corresponderiam às duas séries de quatro quadras que compõem o primeiro e o segundo movimentos do poema, sendo «flácidas» a caracterização quando aparece no contexto de um relativo desequilíbrio: a sextilha que finaliza. Os «tijolos» são os versos que se sobrepõem no «desenho» total. A «magia» deste se efetua porquanto parece não ser «lógico», antes revolto, o processo de substituição dos quali- 
ficativos e substantivos, anunciados no primeiro movimento, no segundo movimento e no finale. Trata-se verdadeiramente de um construto verbal engenhoso no qual a aparente arbitrariedade da nova consignação dos elementos em jogo conduz simultâneamente a efeitos verbais de maravilha e à transmissão da mensagem de reivindicação social do operário desprotegido.

O derradeiro sintagma da narração efetuada através dos versos -esmagamento do corpo do sujeito na rua- veste-se de ressonâncias grotescas; as metáforas insólitas a que se chega por meio do re-arranjo dos vocábulos projetam uma luz algo irreal sobre os acontecimentos. Tudo é feito num tom de alta ironia; a quase épica do herói, plasmada em harmonia verbal contrapontística, acompanhada por uma música de crescendo e complexidade sutilmente graduais, termina numa cena que não faz mais do que estar «atrapalhando o tráfego... público... sábado», À vista desta estrutura elaborada, e dos artifícios empregados na distribuição e ampliação dos signos, atribuir uma etiqueta (neo) barroquista a esta composição não é nada atrevido.

A música declamatória "Deus lhe pague», embora apareça inteira no início do disco Construção, re-aparece, agora reduzida pela metade e contextualizada, como coda à música titular. Nesta instância não há cesura musical entre as duas composições e estas se ligam tanto por força de metonímia quanto pelas áreas de referência que estabelecem. A peça maior mostra uma interessante intratextualidade apartir do título; a contraparte se insere irônicamente num contexto linguiístico mais extenso, pertencendo ao acervo comum de ditados de origem religiosa e pedindo o título a veIhos sambacanções/boleros sentimentais, como «Deus the pague» de Penazzi e Nasser (gravada por Ângela Maria).

A versão do Chico é prelúdio e continuação lírico-musical do dramatismo de «Construção» e amplia o aspecto grotesco da visão da vida brasileira; o caso particular da música maior, representada na menor no verso «Pelos andaimes pingentes que a gente tem que cair», prolifera numa série de condições de vida miserável que são irônicamente «agradecidas» no refrão «Deus lhe pague». O eco desta sátira remonta até as arremetidas de Gregório de Matos contra a maldade e a corrupção prevalentes na Bahia colonial.

Até certo ponto, todas as músicas do Chico Buarque comentadas aqui participam de um fenômeno artístico que Severo Sarduy associa à essência da mentalidade barroca: a elipse. Mais do que o significado retórico tradicional do termo - a supressão de um elemento de uma sentença- o elíptico aqui denota a supressão de sentenças judicativas inteiras que pertenceriam ao discurso maior proposto pelas músicas. Na medida em que 
canções como «Pedro Pedreiro» e «Construção» brincam com a linguagem e com a imagem oficial de um Brasil feliz e justo, sem tal dizer, isto é, implicar ou inferir julgamentos negativos enquanto verbaliza ao redor de uma situação dada (e não diretamente sobre ela), são barrocamente elípticas. A declaração de uma conclusão, para falar a verdade, não faz falta; a supressão presta certa eficácia ao texto. Trata-se de transformar uma imposição negativa (a restrição da censura, inevitável na época destas músicas) em um êxito no plano estético: a elipse, mais eficaz que a retórica óbvia.

Noutra composição do Chico a importância do sugerido, do não nomeado, do referente eludido, é de primeira ordem. Na extensidão dos ver-

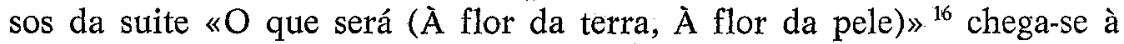
elipse do sujeito e a uma ambigüidade mais diretamente assoviável à poética dos Seiscentos do que os poemas acima apresentados.

"A flor da terra» consiste em trinta e oito versos impessoais (verbos em terceira pessoa, sem auto-referência do cantante lírico) que caracterizam através dos seus efeitos, aparições, potencialidades e dimensões, um ente, por sinal nunca especificado. Trata-se de uma proliferação de alusões, afirmações e negações, e indicações ao redor de um eixo invisível: as rodas, os pneus e as engrenagens funcionam e giram -o texto se mexe, o corpo veiculado se movimenta- mas o eixo está propositadamente encoberto, assim como o motor-gerador. O texto sugere algo ubíquo e abertamente conhecido - parte da existência e experiência humanasmas de forma secreta, não revelada: «... que estão falando alto pelos botecos... Está na fantasia dos infelizes... Está no dia a dia dos meretrizes... O que não tem certeza nem nunca terá... (gravação, Meus caros amigos, Phonogram, 6349189, 1976). Como este último exemplo, há muitos versos que configuram um significado indefinível e inabrangível: «... O que não tem conserto nem nunca terá... O que não tem tamanho... Em todos os sentidos... será que será... o que não tem decência nem nunca terá... o que não tem censura nem nunca terá... o que não faz sentido... o que não tem governo nem nunca terá... o que não tem vergonha nem nunca

${ }^{16}$ A primeira parte foi gravada pelo compositor, a segunda pelo Milton Nascimento no disco Geraes (EMI, Odeon 064-422806D) -com mútuas participações especiais- e a terceira aparece na trilha sonora do filme Dona Flor $e$ seus dois maridos. Esta terceira parte fica fora da discussão por ser mais diretamente entendível como encomenda para o filme, embora o texto em si se sustente sem necessárias ligações com o contexto fílmico. Há nesta versão certa particularização pessoal, referências a personagem, que em certa medida «respondem» à pergunta da canção. A gravação de Simone (EMI Odeon 064-82436D) inclui a versão fílmica, composta de versos de «Á flor da pele» e outros novos. 
terá... o que não tem juízo...» Esta forma elusiva remete o texto ao plano, por assim dizer, da adivinha gigantesca: a quadra popular se expande em um enorme ponto de interrogação onipresente no espaço poético sugerido e no espaço humano implicado.

O segundo movimento da suite continua a não-delimitação do sujeito: «... o que não tem medida... remédio... receita... descanso... cansaço... limite...» Nesta parte da proliferação (mais trinta e seis versos) a mesma imprecisão e o mesmo aspecto quase misterioso ou mágico da primeira parte estão presentes, porém, o falante/cantante lírico já associa «o que será» a si próprio («... que me dá... que me bole...») e ao grupo que o engloba («... que dá dentro da gente...»), e a dimensão corporal domina («... por dentro... à flor da pele... olhos... peito... sou...»). Assim, sugere-se como que uma praga ou possessão diabólica que incomoda de todas as maneiras. Os efeitos, as projeções, as associações do «quê» podem ser mais localizáveis, mas o «quề em si, não. O enigma, pois, toma força apesar de um espaço manifestante mais íntimo.

Nas duas partes configura-se um ponto de interrogação, indagação, auto-questionamento, reflexão larguíssima sobre o ser humano. Não haverá certeza nas respostas a tudo isso. Certas alusões sugerem a dimensão erótica ( «... amantes, ... na natureza...», reações físicas, o fato de ser universal) em contraposição ao mecanismo repressor da religião, da Igreja («padre eterno... inferno... mandamentos», implicações de pecado e de culpabilidade), mas a ambiguiidade e multi-dimensionalidade do conjunto de versos criam, por cima deste possível enfoque, um universo maior, uma dimensão da existência - a experiência humana in totum- que englobaria qualquer linha explicativa singularizada. Daí a força barroca do texto - a maravilha do ouvinte perante a abundância verbal e perante seu universo com efeito infinito.

Este texto questionador "O que será» propõe um significado etéreo, vago, que se espalha indeterminadamente através de cláusulas nominais. Outro texto da MPB da mesma época - meados dos setenta- consegue um efeito parecido ao enumerar como que caoticamente elementos de uma natureza circundante, apenas pontilhando-se de determinadas enunciações não concretas que iluminam a riqueza do corpo verbal. «Águas de março», talvez o ponto mais alto do compositor Antônio Carlos Jobim (a grande maioria de suas músicas mais destacadas tem letra de parceiro), também impressiona à primeira vista (audição) pela extravagância ornamental: a canção tem mais de cinco dúzias de frases e quase todas elas simplesmente assinalam a existência de certo elemento ou de certa coisa natural. 


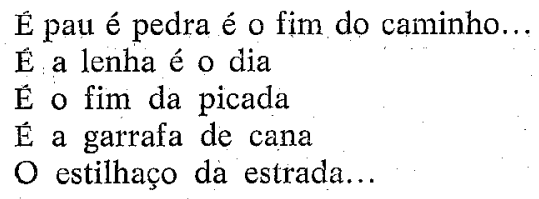

(Gravação Elis-Tom, Phonogram $6439-112,1974$.

O conjunto de enunciações leva inicialmente a duas observações: trata-se de uma letra inusitada que, à guisa de determinados textos de Chico Buarque, surpreende pela extensão em comparação com a parcimônia da massa de canções de seu tempo, e essa mesma extensão leva também à formulaçẩo de uma pergunta fundamental $\mathrm{em}$ face do texto: há uma equivalência entre a série de coisas designadas ou algum sujeito englobador não nomeado? Ou todas estas percepções/imagens colhidas bastam a si, independentes ou em conjunto, num mundo lírico autônomo? Isto é, todas as partículas naturais, e as ocasionais atividades humanas sugeridas, são metáforas particularizadas/símbolos de um sujeito maior (o «indefinido» na música de Gil, o «que será» na música do Chico), ou a série não tem intenção (nem a manifesta) de trascender o nível visual e algo emotivo? É neste sentido que é atribuível a «Águas de março» um carater barroquista: certa não discursividade lógica, a ambiguiedade essencial em um molde bizarro e polifônico.

A plurivalência do texto, conforme se opinou no caso de «O que será» acima, permite uma interpretação erótica sem reduzir o texto a esse único nível. Nesta composição de Jobim, o aspecto amoroso - herança do modinismo sentimental de que Mário de Andrade falava - pode dar conta eventualmente do texto. A única frase pluralizada compõe o refrão e revela possíveis esperanças do cantante lírico:

\section{São as águas de março Fechando o verão \\ É a promessa de vida \\ No teu coração...}

Ao estender essa associação, se pode enxergar o texto e seus constituintes múltiplos como expressão de um «mood» esperançoso espalhado e projetado no mundo circundante. Esta explicação nos coloca no âmbito de um romantismo, não inteiramente impensável dada a função sóciopsicológica tradicional da canção em geral, mas insuficiente para resolver, ou sintetizar, cutros elementos na totalidade do texto. Se este mesmo aspecto amoroso se considerar não como conclusão, nem ponto de referên- 
cia para os demais, senão como outro ponto da série, isto é, membro (se bem que seja ideal, não táctil ou visual) do conjunto e não seu regedor, então outro par de versos do reino do intangível pode dar a chave para quem quiser levar o afã analítico às últimas conseqüências:

$$
\begin{aligned}
& \text { É um mistério profundo } \\
& \text { É o queira ou não queira... } \\
& \text { É a vida é o sol } \\
& \text { É a noite é a morte... }
\end{aligned}
$$

Concebido assim o texto volta à pergunta inicial que coloca ou inspira; no fundo as perguntas metafísicas que têm atormentado o homem desde que começou a refletir sobre os mistérios cósmicos, o absoluto último, o «tudão» nas palavras de João Gilberto. Ao mesmo tempo esta inconclusividade frisaria o aspecto auto-suficiente e lúdico do poema, o qual é mais do que indicativo da natureza barroquista de «Águas de março».

A sonoridade do texto se apóia no seu ritmo retalhado mas incessante e no jogo das aliterações que o povoam: "É o vento ventando... $\hat{E}$ a viga o vão... É a chuva chovendo... É pau, é pedra... É um pedaço de pão, é o fundo do poço... é um estrepe, é um prego / É uma ponta, é um ponto / é um pingo pingando...» A variedade aparentemente arbitrária dos sons aproveitados se concatena com duas tendências imagéticas que também participam da abertura ou inconclusividade barroquista da canção: 1) o estilhaçamento ( caco, resto, pedaço, estilhaço, corte...») e 2) a viagem finda mas sem destino ( «fim do caminho, pé no chão, marcha, ponte, fim da picada...»). Esta construção lúdica de imagens na última instância é a imagem do construto verbal refletida sobre si próprio.

Resta mostrar que esta intratextualidade é também intertextualidade. Por uma parte pode argumentar-se que o texto deste compositor se insere numa noção paradigmática estabelecida a partir de Olavo Bilac. Affonso Romano de Sant'Anna opina que Jobim «reconstrói um sentido próprio num tratamento verbal e sonoro original» ao retomar o bardo parnasiano como epígrafe:

Foi em março, ao findar das chuvas quase à entrada

Do outouno, quando a terra, em sede requeimada,

Bebera longamente as águas da estação.

( $\mathrm{O}$ Caçador de Esmeraldas») ${ }^{17}$.

${ }^{17}$ Romano de Sant'Anna, Música popular, p. 221. A gravação original, Disco de bolso, I: 1 (1972), vem acompanhada da letra escrita com os versos de Bilac ao lado. 
Acima deste vínculo, talvez inesperado para muitos, parece ainda mais nítida a relação que "Águas de março» mantém com uma forma do canto folclórico marcada — ao lado dos gêneros irmãos o coco e a emboladapor seus traços lúdicos: o samba de matuto ${ }^{18}$. Assim, o texto de Jobim não só dialoga com um texto parnasiano culto, como também com uma quantidade inumerável de criações verbais populares que procedem ilogicamente e por «nonsense» no seu contexto lúdico (diversão popular). Esta possível síntese do culto enigmático-erótico e do divertido de raíz popular dá-se aqui em um texto determinado enquanto tal tipo de bipolaridade se percebe na obra geral de um Gregório de Matos colonial; mas as sensibilidades poéticas que filtram os ingredientes, particulares e generalizadas respectivamente, devem compartilhar através dos séculos mais do que paralelos coincidentais.

Os textos dos parceiros do músico João Bosco, que começam a fazer sua contribuição no âmbito lírico da MPB na época da acima destacada música do mestre da bossa nova, mostram semelhanças impressionantes com aquele texto único de Antônio Carlos Jobim. Antes de considerar esses aspectos da abundancia lúdica, porém, é interessante indicar o relacionamento de Aldir Blanc e Paulo. Emílio com a série literária. Em uma parceria do primeiro, composição de vários níveis, não só trata uma imagem criada por Bilac, como toma emprestado o título e o personagem do

${ }^{18} \mathrm{O}$ tema do "pau e pedra» dá lugar a longas discussões. O pesquisador encarregado do disco-revista sobre Jobim na coleção, Nova História da Música Popular Brasileira (São Paulo: Abril Cultural), diz que a música «Âguas de março» se relaciona com o «samba de maracatu», exemplificando com uma gravação de Carlos Galhardo dos anos trinta, «Pisa Baiana», que começa com este verso. Embora seja gênero irmão o «samba de maracatu», peritos nestas questões de folclore lírico nordestino prefeririam uma associação com o «samba de matuto», forma alagoana, sergipana e baiana do interior. O mestre nesta área, Theo Brandão, em conversa pessoal com este autor, confirma que esta forma de canto deve classificar-se assim. Ver dele, Trovas populares (Maceió: Caete, 1951) e Folclore de Alagoas (Maceió: Ramalho, 1949), assim como uma série de folhetos sobre folclore editados pelo estado de Alagoas.

Hermilo Borba Filho, autor de Espetáculos populares do nordeste e outros livros afins, inclui em seus romances o gênero do "samba de matuto»: ver Os ambulantes de Deus (Rio de Janerio: Civilização Brasileira, 1979), pp. 36 e 141; Sol das almas (Rio: Idem, 1964), p. 4. Apenas para indicar a extensão do «pau e pedra» como motivo popular, ver Baptista Siqueira, Origens do termo samba (Rio de Janerio: INL, 1978), p. 140, onde exemplifica a presença de raízes nordestinas nas práticas musicais do Rio com uma quadra que começa «É pau é pedra». No que diz respeito aos aspectos lúdicos na cantoria de desafio nordestina, ver Augusto de Campos, capítulo final de Verso Reverso Controverso (São Paulo: Perspectiva, 1978). 
poema citado para parodizar numa canção o namoro moderno burguês ${ }^{19}$. A versão cantada por Bosco aproveita até o conhecidíssimo refrão do romance de García Lorca para começar sua sátira e reflexão sobre a relação paixão/dinheiro: «Verde que te quiero oro...» A imagem do verde permeia este exercício de distorsão lúdica e grotesca, havendo certa fábrica antitética que mostra um carater justaposicional algo barroquista: «Fernão se esmerava na conquista / de Esmeralda, inferno de Fernão.» Finalmente o namoro enfocado na lente deformadora da música liga o personagem histórico seiscentista com o «divertissement bourgeois» do Rio de Janeiro atual: «o enleio dos delirantes / no Recreio dos Bandeirantes», alusão que também se reporta ao âmbito do famoso poema de Bilac.

A propósito dos insólitos parceiros de Bosco exprimiu sua admiração o crítico Affonso Romano de Sant'Anna em 1975, afirmando que «na relação entre o texto de Aldir e Paulo Emílio com a literatura não há uma subordinação, mas um manuseio livre e sem referências a uma fonte direta ${ }^{20}$. Reconhecem-se, todavia, algumas dessas referências, e algumas ligam o dizer destes parceiros líricos modernos com avôs longínquos como - Gregório de Matos do soneto "Aos efectos e lágrimas derramadas na ausência da dama a quem queria bem»; é o caso da canção «Corsário»:

\author{
Meu coração tropical \\ Está coberto de neve, mas \\ ferve em seu cofre gelado ${ }^{21}$.
}

Se este exemplo isolado lembra imediatamente o conhecido soneto do mestre da mistura trópico-continental, a voz do oxímoron da Bahia, uma série de letras feitas para João Bosco irmanam-se com o barroco da abundância ornamental percebida em «Águas de março», à qual se aludiu acima. Na composição titular do disco-show de Bosco de 1979, Linha de passe (RCA, 103 0294), os dois parceiros líricos cooperam num texto enumerador que muito deve aos seus efeitos sonoros, criados sobre a base de uma imagem futebolística e outras culinárias:

19. «O Caçador de esmeraldas» (Bosco-Blanc-Cláudio Tolomei) do disco A Música de João Bosco e Aldir Blanca (Fontana, 6488 106). O título de Bilac já fora usado por O. Santiago-H. Porto e por Joubert de Carvalho. A utilização não é, então, coisa tão inovadora, mas o desenvolvimento do texto é certamente inusitado.

${ }^{20}$ Romano de Sant'Anna, Música popular, p. 260.

${ }^{21}$ A falta do disco original aqui nos Estados Unidos, consultou-se o programa do show «Linha de passe» de João Bosco, roteiro e textos de Aldir Blanc e Paulo Emílịo, Rio de Janeiro, Teatro da Gávea, 1979. 
Toca de tatu, linguiça e paia, boi zebu rabada com angu, rabo de saia...

e hoje em dia rola a bola, é sola, esfola, cola, é pau a pau e lá vem Portellas que nem Marquês de Pombal...

O aproveitamento da herança tupi é mais evidente em outros textos, onde há, por assim dizer, uma «descomunicação», importando acima de tudo as funções poética e metalinguiística:
Suco de surucucu
diga lá jacu
cutia comadre
posta de piracuru...
saúva coruja
rastro de jararticu
jararacoral
piranha corunga
diaba de banda retraí
de carataí...

(«Cobra criada», Bosco-Emílio, disco citado.)

Este tipo de desbordamento recurre em «Sudoeste» da mesma dupla:

O vento deu no matagal e deu na cara dos cajás no coqueiral, nas borboletas, azulão, nos curiós jaca manteiga, jaca mãe, no bambuzal, nas teias tristes do porão, caramanchão, capim navalha coração.

Fora os exemplos de direta ligação com o passado literário, o fazer lírico de Blanc e Paulo Emílio se associa com o barroco através do jogo verbal, por vezes extremamente ornamental ou bizarro, mas sempre baseado no contexto linguístico americano e brasileiro. E assim uma observação do famoso prosador e ensaísta cubano Alejo Carpentier vale no contexto da música popular brasileira dos anos setenta: «Nuestro arte siempre fue barroco... barroquismo creado por la necesidad de nombrar las cosas» ${ }^{22}$.

Muitas composições brasileiras de fins da década passada mostram

${ }^{22}$ Alejo Carpentier, Tientos y diferencias (México DF: UNAM, 1964), pp. 42-43. 
afinidades com o ludismo barroquista visto nos parceiros de Bosco. Elas nem sempre são tão visuais quanto no caso daquelas vozes. O poeta Antônio Carlos Brito, conhecido em círculos artísticos pelo apelido Cacaso, é muito consciente deste tipo de potencialidade lírica e a leva a níveis auto-reflexivos. Em parceria com Edu Lobo, cria um (auto) retrato jocoso do brasileiro através de recursos que incluem séries caracterizadoras ambíguas e até contraditórias e desafios paradoxais debochados que ressoam até a conceitismo ibérico dos tempos de Quevedo, lembrando também o Camões antitético de «O amor é fogo que arde sem se ver».

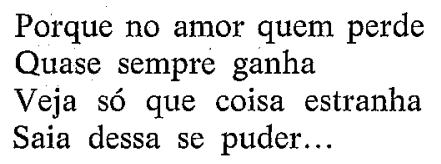

(«Lero lero», disco Camaleão, Polygram $63490-350,1979$.

Há auto-referências e caracterizações nesse mesmo texto que se relacionam simultâneamente com os aspectos enigmático e não discursivo da lírica:

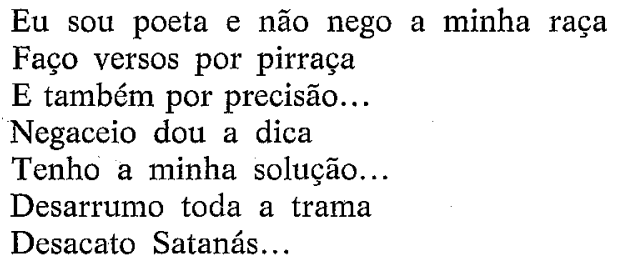

E ao lado de poetas-letristas que se exprimem (ou dos textos que se exprimem através deles) deste jeito essencialmente lúdico, há outros cuja expressão lírico-amorosa lembra os cantos estilizados do Seiscentos. O cearense Brandão, por exemplo, configura paixões contraditórias numa veia comumente associada àquela época:

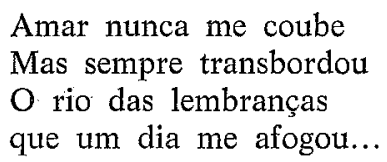




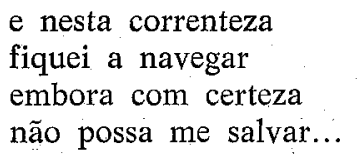

(«Esquecimento» de Fagner-Brandão, disco Orós, CBS 230010, 1977.)

No caso poderia tratar-se de um desengano barroco na moldura de imagens naturais que sugerem ao mesmo tempo a preocupação com a salvação da alma e as viagens oceânicas daquela época. No texto o objeto da memória do cantante lírico não é delimitado; o texto depende de justaposições algo ambíguas, nas quais o irresolúvel significa uma angústia conceitual e emocional:
Amar nunca me trouxe
Completo esquecimento
mais sempre me somou
ao antigo tormento
e assim cada vez mais
me prendo neste nó
que cada grito meu
parece ser maior.

Um dos engenhos do texto se efectua a nível fônico (na maioria dos dialetos brasileiros): o «mas» da primeira estrofe funciona como conjunção, enquanto seu correlativo na terceira vira comparação quantitativa, o qual intensifica o «tormento» descrito. A estruturação das ideias, porém, continua sendo o forte do texto. O raciocínio e os impulsos contraditórios, vistos nesta primeira música, também modelam o texto: «Dois querer», do mesmo autor. Antepondo o desejo da mobilidade ao da permanência, configura uma superfície que cobre uma multiplicidade de desejos reprimidos:

Tem muito querer debaixo

desses dois querer

Como água no riacho

Barrada para não correr.

(Gravação Raimundo Fagner, CBS 230040, 1980.) 
O texto finda no «mormaço» da conformidade, imagem meteorológica da vida sem definições precisas («céu azul... sem chover»), conciliando se não resolvendo um conflito intra e extra textual anunciado no início da canção: «A palavra só não liga / Dois querer que são os meus...» Sem compartilhar certos aspectos formais característicos do barroco ibérico de há tres séculos, estas composições dialogam sem dúvida com aquela sensibilidade lírica que produziu construtos verbais que refletiam estados de alma contraditórios ou contrários.

Os exemplos oferecidos aqui do lirismo de Brandão, junto com os de Gilberto Gil de início comentados, são indicativos de relações líricas transtemporais no nível da ordenação retórica. Outros casos -Blanc, Cacaso, etc.-- mostram uma intimidade verbal e noções estéticas cuja proximidade do barroco (ou inclusão num neobarroco) está mais no que diz respeito à funcionalidade poética e metalingüística do verso, ênfase característica de grande parte da poética seiscentista, do que no que tem a ver com as funções emotiva ou apelativa da linguagem, relativamente enfatizáveis em certas manifestações da literatura barroca (poesia amorosa, doutrinária). $\mathrm{E}$ as composições de Chico Buarque enfocadas acima devem muito de seu parecido com o barroco ao aspecto da elaboração arquitectônica e elíptica. Com isto quer se dizer que o que pode haver de barroquismo nos textos de música popular brasileira contemporânea percebe-se em pontos diferentes de um espectrum largo. A re-atuação de vários aspectos da concepção lírica da época de Gregório Matos - a não ser no caso da duplicação moderna de um texto específico, caso de Caetano Veloso com «Triste Bahia»- forçosamente há de mostrar, mesmo ao compartilhar o pão ou ao travar amizade íntima, sua diferença. Numa manifestação artística como a canção na qual fatores comerciais e de moda pesam tanto, não se poderia esperar que este tipo de diálogo com os tempos coloniais fosse muito comum. Mas haverá menos dúvida acerca da vitalidade do barroco hoje em dia ao verificar que até na interseção das séries literária e musical nas últimas duas décadas no Brasil esse diálogo se escuta. Quem quiser sentir esta relação de perto, escute a recente gravação de Caetano Veloso, Outras palavras (Phillips, 6328-203, 1981) e preste atenção:

Quase João Gil Ben muito bem mas barroco como eu... 
